\title{
Effective factors on mobile phone customer satisfaction
}

\author{
Hamed Mohafez ${ }^{a}$, Vahidreza Mirabi ${ }^{\text {b* }}$, Bahram Kheyri ${ }^{\text {b }}$
}

${ }^{a}$ Department of Management, Science and Research Branch, Islamic Azad university, Tehran, Iran ${ }^{b}$ Department of Management, Central Branch, Islamic Azad university, Tehran, Iran

\begin{tabular}{|c|c|}
\hline A R T I C L E I N F O & A B S T R A C T \\
\hline $\begin{array}{l}\text { Article history: } \\
\text { Received June 2, } 2011 \\
\text { Received in Revised form } \\
\text { October, } 19,2011 \\
\text { Accepted } 28 \text { December } 2011 \\
\text { Available online } \\
27 \text { January } 2012 \\
\text { Keywords: } \\
\text { Customer satisfaction } \\
\text { Cellular phone industry } \\
\text { Perceived expectations } \\
\text { Perceived quality } \\
\text { Perceived value }\end{array}$ & $\begin{array}{l}\text { Cellular phone is one of the most profitable industries in the world and especially in middle east } \\
\text { regions. There is a growing competition among different firms in this market and the market } \\
\text { share is exchanged very quickly depending on the features and equipments introduced. } \\
\text { Customer satisfaction plays an important role on retaining present marker share or absorbing } \\
\text { new customers. In this paper, we present an empirical study to measure the effects of different } \\
\text { factors influencing customer satisfaction such as the effect of perceived expectations on } \\
\text { perceived quality and the effect of perceived expectation on perceived value. The survey is } \\
\text { performed among customers who live in Tehran, the capital city of Iran and it shows there are } \\
\text { some meaningful and positive relationship between perceived expectations and other factors } \\
\text { such as perceived quality and perceived value. There is also positive relationship between } \\
\text { perceived quality and perceived value. perceived expectation and customer satisfaction. }\end{array}$ \\
\hline
\end{tabular}

Perceived value

\section{Introduction}

Mobile phone has changed the way people communicate, traditionally and it has part of many people's life style. In some countries, most of the teenagers as well as older people consider Mobile devices as one of their regular home expenditures (Fornel, 1992; Hellier et al., 2003; Chan et al., 2003; Vilares \& Coelho, 2003; Hagg \& Jonsson, 2009). There is also a strong competition among different mobile device providers. Boulding et al. (1993) presented a dynamic process model of service quality in terms of expectations to behavioral intentions based on Bayesian like framework. They viewed perception of the dimensions of service quality as a function of a customer's previous and present expectations. Their findings indicated that two different types of expectations had opposing impacts on perceptions of service quality and service quality perceptions had a positive correlation with intended behaviors.

Anderson et al. (1994) discussed the relative importance of service quality, customer satisfaction and customer value as the most important factors of business success for both manufacturers and service providers. However, they argued that there are different conclusions about the definition of customer

* Corresponding author. Tel: +09123780512

E-mail addresses: hamedmohafez@yahoo.com (H. Mohafez) 
value. They proposed a model for measuring the service quality in China's mobile phone market based on the well-known SERVQUAL model. In their implementation, they provided some discussions among some expert to extract useful opinions to reflect the specific industry attributes and the special culture of China. They also studied the dynamic relationships among service quality, customer value, customer satisfaction and their influences on future behaviors after they identified some important components of customer value and customer satisfaction. Andreassen and Lindestad (1998) studied customer loyalty and complex services by measuring the impact of corporate image on quality, customer satisfaction and loyalty for customers with varying degrees of service expertise. Bruhn and Grund (2000) presented theory, development and implementation of national customer satisfaction indices (SWICS).

Aydin and Ozer (2005) presented Structural equation modeling in the specific context of the mobile telephone market in Turkey by gathering data through questionnaire from over 1,500 subscribers. They reported that their new customer satisfaction index provides better fit and strong explanatory power. Ball et al. (2004) explained that customer loyalty could be described by customer satisfaction, trust, and communication. They also discussed that the direct and indirect effects among those constructs and other constructs in an extension of the European Customer Satisfaction Index (ECSI) model. They estimated both ECSI and the extended models with data from a survey carried out among customers of the banking sector and discussed some of their findings.

Eklöfa and Westlund (2002) presented a comprehensive study on pan-European customer satisfaction index work and the way. Hsu et al. (2006) presented a research in customer satisfaction by demonstrating how a customer satisfaction could help some important questions such as why customers are satisfied or they are not satisfied, whether a particular firm handles complaint properly or not. They performed an empirical survey using 532 customers served by a commercial banking organization on Taiwan. The results indicated that there are some differences in satisfaction levels among various genders.

Sattari (2007) implemented the application of disconfirmation theory on customer satisfaction determination model in mobile telecommunication. Turel and Sereko (2006) examined the antecedents of customer satisfaction and loyalty through an empirical investigation of 210 young adult mobile phone subscribers in Canada using the American Customer Satisfaction Model. They calculated the satisfaction index of young adult Canadians offered insights for service providers, policymakers and subscribers; and forms the foundation for future benchmarking of the performance of wireless network operators in terms of user satisfaction and loyalty. Wang et al. (2004) presented an integrated framework for customer value and customer relationship management.

The proposed study of this paper presents an empirical study to measure customer satisfaction for mobile users in a city of Tehran, Iran. This paper is organized as follow. We first present details of our eleven hypotheses in section 2. Section 3 presents the results of our study and finally concluding remarks are given in the last to summarize the contribution of the paper.

\section{The proposed study}

The proposed study of this paper adopts a framework originally presented by Turel and Serenko (2006). Based on their model, there are some relationship between perceived quality (PQ) and perceived expectation (PE) and perceived value (PV). There is a relationship between perceived value (PV) and customer satisfaction (CS), there are some relationship between customer satisfaction (CS) and repurchase likelihood (RL). Finally, there is a relationship between price tolerance (PT) and customer complain (CC), and there is a relationship between CC and RL. Fig. 1 shows details of the proposed model. 


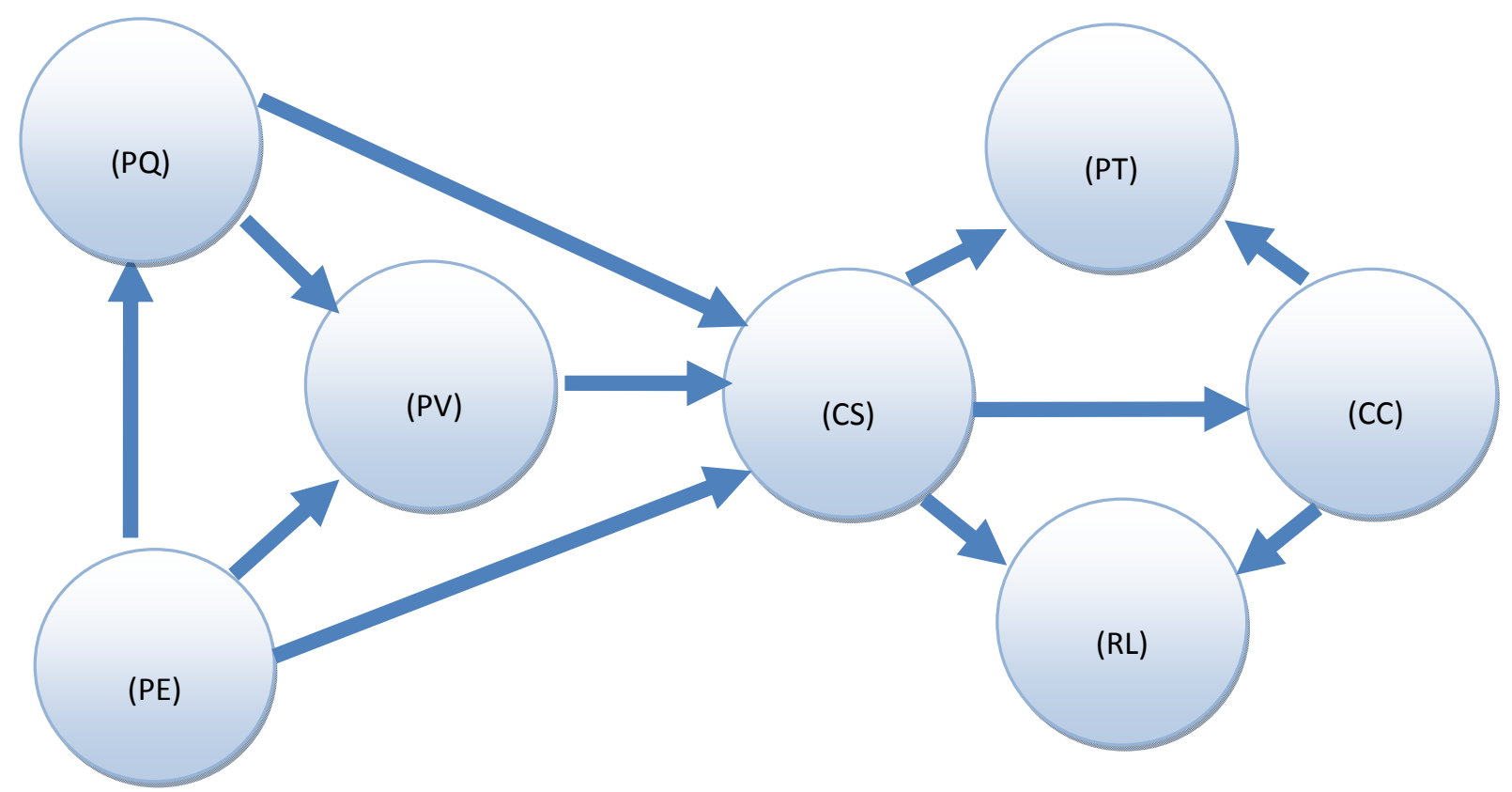

Fig. 1. The adapted proposed model (Turel \& Serenko, 2006)

The proposed study of this paper considers the following eleven hypotheses.

1. H1: Perceived expectation (PE) influences on perceived quality (PQ) of Mobile services.

2. H2: Perceived expectation (PE) influences on perceived value (PV) of Mobile services.

3. H3: Perceived quality (PQ) influences on perceived value (PV) of Mobile services.

4. H4: Perceived expectation (PE) influences on customer satisfaction (CS) of Mobile services.

5. H5: Perceived quality (PQ) influences on customer satisfaction (CS) of Mobile services.

6. H6: Perceived value (PV) influences on customer satisfaction (CS) of Mobile services.

7. H7: Customer satisfaction (CS) influences on repurchase likelihood (RL) from a particular vendor.

8. H8: Customer satisfaction (CS) influences on price tolerance (PT) from a particular vendor.

9. H9: Customer satisfaction (CS) influences on customer complaint (CC) from a particular vendor.

10. H10: Customer satisfaction (CS) influences on repurchase likelihood (RL) from a particular vendor.

11. H11: Customer complaints (CC) influences on price tolerance (PT) from a particular vendor.

We use the following sampling procedure to determine suitable number of sample size,

$n \geq \frac{z_{\alpha / 2}^{2} \times p q}{e^{2}}$

where $z_{\alpha / 2}$ is the normal distribution, $e$ is the error term, $p$ is the likelihood of the event and $q=1-p$ and $n$ is the number of sample size. In our study we use $z_{\alpha / 2}=1.96, e=0.06, p=q=0.5$, which yields $n=384$. In our survey, we distributed 400 questionnaire and collected 396 completed responses. The sampling was held randomly in various locations of city of Tehran and Table 1 shows details of our sampling. 
Table 1

Characteristics of sampling in different locations of the city

\begin{tabular}{llccc}
\hline Direction & Region & Population & Percentage & Sample size \\
\hline North & $1,2,3,4$ & 2154337 & 26.746 & 107 \\
East & $8,13,14$ & 1202389 & 14.927 & 60 \\
Center & $6,7,10,11,12$ & 1413672 & 17.551 & 70 \\
West & $5,9,21,22$ & 1130078 & 14.030 & 56 \\
South & $15,16,17,18,19,20$ & 2154154 & 26.755 & 107 \\
\hline Sum & & 8054630 & 100.00 & 400 \\
\hline
\end{tabular}

We also use Cronbach Alpha (Cronbach, 1951) to validate the results of our survey using a sample including 50 people and it yielded 0.874 , which was well above the minimum desirable level of 0.70 .

\section{Results}

In this section, we present details of our findings from our survey. Table 2 shows details of our findings in terms of Pearson correlations ratios between each pairs of the items. They represent details of our findings for the first five hypotheses. As we can observe, there is a positive correlation between PE and PQ, between PE and PV, between PQ and PV and PQ and CS and P-values are less than $5 \%$, which means the results are meaningful. There is also a negative correlation between $\mathrm{PE}$ and CS with valid P-value.

Table 2

Pearson correlation ratios for hypothesis 1 to 5

\begin{tabular}{lccccc}
\hline & PE-PQ & PE-PV & PQ-PV & PE-CS & PQ-CS \\
\hline Correlation & $.167\left(^{* *}\right)$ & $.157\left(^{* *}\right)$ & $.435\left(^{* *}\right)$ & $-.161\left(^{* *}\right)$ & $.659\left(^{* *}\right)$ \\
P-value & .001 & .002 & .000 & .001 & .000 \\
\hline
\end{tabular}

In addition, Table 3 shows details of our findings for hypothesis 6 to hypothesis 11 . As we can observe from the results of Table 3, there is a positive and meaningful relationship between PV and CS, between CS and RL. In addition, there is a meaningful negative relationship between CS and CC, between CS and CC and between CC and PT. Our result indicates that there is no meaningful relationship between CS and PT.

Table 3

Pearson correlation ratios for hypothesis 6 to 11

\begin{tabular}{lcccccc}
\hline & PV-CS & CS-RL & CS-PT & CS-CC & CS-RL & CC-PT \\
\hline Correlation & $.505\left(^{* *}\right)$ & $.480(* *)$ & $-.016(* *)$ & $-.498(* *)$ & $-.459(* *)$ & $-.135\left(^{* *}\right)$ \\
P-value & .000 & .000 & .749 & .000 & .000 & .008 \\
\hline
\end{tabular}

We have also performed a regression analysis between customer satisfaction as dependent variable and perceived quality (PQ), perceived expectation (PE) and customer complain (CC) and the results are summarized in Table 4.

Table 4

Regression analysis between Customer satisfaction as dependent variable and PQ, PE and CC

\begin{tabular}{lrrrrr}
\hline & \multicolumn{2}{c}{$\begin{array}{l}\text { Unstandardized } \\
\text { Coefficients }\end{array}$} & $\begin{array}{r}\text { Standardized } \\
\text { Coefficients }\end{array}$ & $\begin{array}{r}\text { t- } \\
\text { student }\end{array}$ & Sig. \\
\hline (Constant) & B & Std. Error & Beta & 5.096 & .000 \\
perceived quality (PQ) & 1.161 & .228 & .481 & 11.525 & .000 \\
perceived expectation (PE) & .499 & .043 & .227 & 5.534 & .000 \\
customer complain (CC) & .203 & .037 & -.174 & -4.163 & .000 \\
\hline
\end{tabular}


As we can observe from the results of Table 4, all t-students are meaningful and $R^{2}=0.321$. In addition all P-values are also meaningful. The results indicate that an increase of one unit of perceived quality will results to an increase of 0.499 on perceived quality, an increase of one unit on perceived expectation will increase 0.203 unit of customer satisfaction but an increase of one unit in customer complaint will reduce customer satisfaction for about 0.125 . We have also implemented another regression model where repurchase likelihood was dependent variable and customer complaint as well as customer satisfaction were independent variables. Table 5 shows our findings.

\section{Table 5}

The results of regression model between CC and CS as independent variables and RL as dependent variable

\begin{tabular}{|c|c|c|c|c|c|}
\hline & \multicolumn{2}{|c|}{ Unstandardized Coefficients } & \multirow{2}{*}{$\begin{array}{c}\text { Standardized Coefficients } \\
\text { Beta }\end{array}$} & \multirow{2}{*}{$\frac{\mathrm{t} \text {-sudent }}{\mathrm{B}}$} & \multirow{2}{*}{$\begin{array}{c}\text { Sig. } \\
\text { Std. Error }\end{array}$} \\
\hline & B & Std. Error & & & \\
\hline (Constant) & 2.905 & .296 & & 9.808 & .000 \\
\hline Customer Complain & -.257 & .044 & -.285 & -5.827 & .000 \\
\hline Customer Satisfaction & .439 & .061 & .350 & 7.162 & .000 \\
\hline
\end{tabular}

As we can observe from the results of Table 5, all t-student values are valid and represent meaningful numbers. Therefore, we can conclude that an increase of one unit in customer complain will results to a reduction of repurchase likelihood of 0.257 . In addition, an increase of one unit in customer satisfaction will increase customer satisfaction for about 0.439 .

\section{Conclusion}

In this paper, we have presented an empirical study to measure the effects of different factors influencing customer satisfaction such as the effect of perceived expectations on perceived quality and the effect of perceived expectation on perceived value. Based on the results of this survey, there was a positive and meaningful relationship between PV and CS, between CS and RL. In addition, there was a meaningful negative relationship between CS and CC, between CS and CC and between CC and PT. Our result indicated that there was no meaningful relationship between CS and PT. There was also a positive correlation between PE and PQ, between PE and PV, between PQ and PV and PQ and CS and P-values were less than 5\%, which means the results were meaningful. There was also a negative correlation between PE and CS with valid P-value.

\section{References}

Anderson, E.W., Fornell, C., \& Lehmann, D.R. (1994). Customer Satisfaction, Market Share and Probability: Finding from Sweden. Journal of Marketing, 58, 53-66.

Andreassen, T.W., \& Lindestad, B. (1998). Customer Loyality and Complex Services. International Journal of Service Industry Management, 9, 7-23.

Aydin, S., \& Ozer, J. (2005). National customer satisfaction index. Marketing Intelligence and Planning, 23(5), 486-504.

Ball, D., Coelho, P.S., \& Machás, A. (2004) The role of communication and trust in explaining customer loyalty: An extension to the ECSI model. European Journal of Marketing, 38(9/10), $1272-1293$

Boulding, W., Kalra, A., Staelin, R., \& Zeithaml, V.A. (1993). A dynamic process model of service quality: From expectations to behavioral intentions. Journal of Marketing Research, 30, 7-27.

Bruhn and Grund (2000). Theory, development and implementation of national customer satisfaction indices (SWICS). Total Quality Management, 11(7), 1017-1028. 
Chan, L.K., Hui, Y.V., Lo, H.P., Tse, S.K. Tso, G.K., \& Wu, M.L. (2003). Consumer Satisfaction Index. European Journal of Marketing, 872-909.

Eklöfa, J.A., \& Westlund, A.H. (2002). The pan-European customer satisfaction index programmecurrent work and the way. Total Quality Management, 13(8), 1099-1106.

Fornel, (1992). A national customer satisfaction barometer. Journal of Marketing, 56(1), 6-21.

Fornell, C., Johnson, M. D., Anderson, E. W., Cha, J., \& Bryant, B. E. (1996). The American customer satisfaction index: Nature, purpose, and findings. Journal of Marketing, 60(4), 7-18.

Hagg, G., \& Jonsson, N. (2009). Branding Strategy Among The Swedish Bank - The micro Company Perspective. Master of Science thesis, University Hogskolan I Halmstad/ Sektionen for Ekonomi och Teknik.

Hellier, P.K., Geursen, G.M., Carr, R.A. \& Rickard, J.A. (2003). Customer repurchase intention. European Journal of Marketing, 37(11/12), 1762-1800.

Hsu, S.H., Chen, W.H., \& Hsueh, J.T. (2006). Application of customer satisfaction study to derive customer knowledge. Total quality management, 17(4), 439-454.

Sattari, Setayesh (2007). Application of disconfirmation theory on customer satisfaction determination model in mobile telecommunication. Master Thesis, Continuation Courses Marketing and e-commerce, Luleå University of Technology, 16-42.

Turel, O., \& Serenko, A. (2006). Satisfaction with mobile services in Canada: An empirical investigation. Telecommunications Policy, 30, 314-331.

Vilares, S.A., \& Coelho, A. (2003). The employee-customer satisfaction Chain in the ECSI model. European Journal of Marketing, 37(11/12), 1703-1722.

Wang, Y., Lo, P.H., \& Yongheng, Y. (2004). An integrated framework for customer value and customer -relationship management. Managing Service Quality, 169-182. 